\title{
Copyright and Fee-Based Copying Services
}

\author{
James S. Heller
}

Many libraries meet the informational needs of their patrons through in-house photocopying services. Financial considerations, however, are requiring more and more of them to recover the costs of operating such services. The Copyright Act of 1976 governs the scope of permissible reproduction and distribution of copyrighted works. The rights of a copyright owner, which include the right to reproduce and distribute copyrighted works, are subject to other provisions of the act that permit copying by libraries. This article discusses the effect of that law upon feebased library copying services.

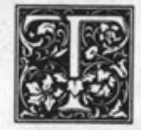

echnological developments that permit rapid and inexpensive document reproduction have allowed many libraries to meet their patrons' informational needs through photocopy services. While many libraries still provide photocopies to persons or organizations outside the library's parent institution at a nominal charge, an increasing number realize the need to recover a greater portion of the actual copying cost. The Copyright Act of $1976^{1}$ governs the scope of permissible reproduction and distribution of copyrighted works. This article examines the impact of the copyright law on fee-based copying services.

The rights of a copyright owner, including the right to reproduce and distribute copyrighted works, ${ }^{2}$ are set forth in Section 106 of the Copyright Act. These rights, however, are subject to the limitations of Sections 107-118 of the act. Under most circumstances, the extent to which a library may provide copies through an inhouse fee-based photocopying service to persons or organizations outside the parent institution will have to be justified under either Section 107 or 108 or the activity will be considered infringing.
The judicially established right of fair use was codified at Section 107 of the act. Section 108 permits, under certain circumstances, copying by libraries and their employees. If copying and distributing copyrighted materials are permitted under Section 107, 108, or another provision of the Copyright Act, the copyright owner need not be contacted for permission, and royalties need not be paid.

An analysis of whether copying is permitted without first having to request permission or pay royalties depends upon the answers to the following questions:

11 . For whom is the material being copied?

2. How is the copy going to be used?

3. What is being copied?

4. How much is being copied?

5. Who is making the copy?

6. How much is the library charging for this service?

7. How are the revenues being used?

As will be seen, some of the questions listed above are identical to those that must be analyzed in determining whether a use is fair under Section 107. First, however, the ability of a library photocopying service to copy and distribute copies under Section 108 will be considered.

James S. Heller is director of the law library and associate professor of law at the University of Idaho, Moscow, Idaho 83843. 


\section{SECTION 108-COPYING BY LIBRARIES}

Section 108 (a)(1)-No

\section{Commercial Advantage}

In order to qualify for the Section 108 exemption a library must first meet the threshold requirements of subsection (a) of Section 108. Section 108(a)(1) requires that copying must be done without a purpose of direct or indirect commercial advantage. The legislative history of Section 108 states that the "advantage" referred to must attach to the copying itself, and that libraries in for-profit organizations, as well as those in public or private nonprofit institutions, may qualify for the Section 108 exemption. $^{3}$

The legislative history infers that a library will not charge more for copies than is necessary to recoup the cost of making those copies. 'A commercial enterprise cannot call itself a library and engage in for-profit copying and distribution without running afoul of the act. ${ }^{4}$ Neither may a library in a nonprofit institution contract with a commercial copying enterprise and authorize it to carry out copying and distribution functions that would be exempt if the library itself did the copying and distribution. ${ }^{5}$ It is therefore proper to examine how much the library charges for its services, and how the money received is used.

A library should be able to recoup the direct and indirect costs of making and distributing copies without removing it from Section 108 protection. Such costs include equipment, utilities, supplies, labor, and postage. Labor costs may be quite substantial, as they include taking the message, identifying, locating and retrieving the material to be copied, making and mailing the copy, billing and record keeping, and reshelving the material copied. ${ }^{6}$

Libraries may find that providing feebased services for outside patrons increases the demand for its services. Charging such sums that permit a library to hire additional staff to meet increased demand should not remove it from Section 108 protection. The labor cost is inherent in providing the service itself, and recouping that cost should not be interpreted to mean that the library has received a "commercial advantage" from the copying.

One may reasonably ask whether there is a commercial advantage if the revenue received from the copying allows the library to add materials to its collection that it otherwise could not afford. If money received from the copying is used to supplement existing resources, the library may actually be profiting from the copying. All costs of operating the copying service should be identified, however, before concluding that revenue is genuinely being used to add materials to the collection.

\section{Section 108 (a)(2)-Open Collection}

Section 108(a)(2) requires that the library's collection must be open to the public or to persons doing research in a specialized field. While there is debate as to whether libraries in for-profit institutions meet this requirement, ${ }^{7}$ this is not likely to be of concern to libraries providing feebased copying services to patrons outside the parent institution. Libraries providing these services are invariably associated with nonprofit organizations such as academic institutions or large public libraries, and have no problem meeting the openness requirement.

\section{Section 108 (a)(3)-A Notice of Copyright}

Section 108(a)(3) requires that "a notice of copyright" be included with the reproduction. There is disagreement as to whether this provision means the formal notice of copyright prescribed by Section 401 or some type of alternative notice. In any event, library photocopying services should comply with this provision. ${ }^{8}$

Assuming that the threshold requirements of Section 108(a) have been met, there are other relevant considerations as to whether specific copying activities are permitted under Section 108. A more detailed analysis of Section 108, particularly subsections (d) and (g), is therefore necessary.

\section{Section 108(d)-Articles and Small Excerpts}

Nearly all copying done by a library photocopying service will be of the nature 
specified in Section 108(d). This provision allows a library to make a single copy of an article or small excerpt from a copyrighted work if (1) the copy becomes the property of the user; (2) the library has no notice that the copy will be used for any purpose other than private study, scholarship, or research; and (3) the library displays warning signs as specified by the Register of Copyrights.'

Generally, compliance with Section 108(d) should not be difficult. First, while a library may provide only a single copy under Section 108(d), rarely will it be asked to provide multiple copies of an article or excerpt when there is a charge for the service. Second, a copy sent to a requester generally becomes his or her property. Finally, in few instances will a library providing copies to noninstitutional clients for a fee know that the use of the copy is for a purpose other than " private study, scholarship, or research." to Should the copy actually be used for an invalid purpose, the library is not prohibited from providing the copy unless it knows of that purpose prior to the copying or distribution of the materials. ${ }^{11}$

\section{Section 108 (g)(1)-Multiple or Systematic Copying}

A library's right to copy and distribute copyrighted material under Section 108 is subject to the limitations of subsection (g). Section $108(\mathrm{~g})(1)$ prohibits related or concerted reproduction of multiple copies of the same material, on one occasion or over a period of time, either for aggregate use by one or more individuals or for separate use by individual members of a group. This provision, however, does not prohibit repeated reproduction and distribution of single copies of the same material on separate occasions to a variety of independent users if each act of copying and distribution is isolated and unrelated, and if the users are not members of a "group."

Although the word "group" is not defined in either the Copyright Act or its legislative history, the purpose of the subsection $(\mathrm{g})(1)$ limitation is to prohibit a library from providing multiple copies of the same material to members of the same organization. In practice, any such activity is generally confined to members or employees of the library's parent institution. The prohibition against related or concerted reproduction of multiple copies of the same material would rarely present a problem for libraries providing copies for a fee to individuals or organizations outside the library's parent institution. In any event, libraries should take precautions to insure that they are not copying beyond that permitted by subsection $(\mathrm{g})(1)$.

\section{Section 108 (g)(2)-Systematic Copying}

Section $108(\mathrm{~g})(2)$ prohibits the systematic reproduction or distribution of single or multiple copies of the type of materials described in subsection (d), namely, articles or short excerpts. ${ }^{12}$ Copying pursuant to interlibrary arrangements, however, is expressly permitted so long as the purpose or effect is not to substitute for a subscription to or purchase of a work. According to Professor Melville Nimmer, subsection $(g)(2)$ prevents a requester from asking for single copies of different articles from the same issue of a journal on separate occasions, thus eventually getting an entire issue, or substantial part thereof, without purchasing it. ${ }^{13}$ A library filling such requests has likely infringed the copyright on a protected work.

The prohibitions created by Section $108(\mathrm{~g})(2)$ appear to be even broader than that suggested by Nimmer if the Guidelines for the Provision of Subsection 108(g)(2) are considered ${ }^{14}$ The guidelines were drafted by the National Commission on New Technological Uses of Copyrighted Works (CONTU) to provide guidance regarding permissible copying for interlibrary loan purposes notwithstanding the prohibition against systematic copying. The guidelines specifically refer to repeated copying from the same journal title, rather than the less restrictive copying from the same issue of a journal. ${ }^{15}$

The purpose of subsection $(\mathrm{g})(2)$ is to prevent copying in such quantities as to reduce the market for a work. This applies whether the market lost is for a specific article from a journal, a single issue of a journal, or a subscription to a journal. The words "same material" in Section 108(g), as applied to subsection (d) materials, pre- 
vent the systematic copying of the same article or different articles from a journal. This is not necessarily true with regard to subsection $(g)(1)$, which appears to prohibit related or concerted copying of identical works.

Multiple copies of the same article will be infrequently requested by a client of a fee-based copying service. Requests are generally coordinated through one department of the client institution, most likely the library, if one exists. Subsequent requests for the same article generally will be filled in-house from the copy previously acquired. ${ }^{16}$ It is nonetheless quite possible that over a period of time the client of a fee-based photocopying service will request a variety of articles from the same journal.

The CONTU Guidelines provide guidance to a borrowing library as to whether making a request for a photocopy is permissible, but they also require that the borrowing library maintain records of requests made. ${ }^{17}$ There is no parallel requirement that supplying libraries keep records of materials copied. However, the Guidelines state that the supplying library may fill a request for a photocopy only after the requesting library has verified that the request complies with the Guidelines. ${ }^{18} \mathrm{It}$ may be difficult for a library copying service to meet this requirement, especially when the institution making the request is not a library. Similarly, technological developments now permit the transmission of requests by means other than the traditional interlibrary loan form. Copying services should consider methods by which they may verify that the required assurance has been made for requests communicated orally, electronically, or by written means, and whether from a library or other type of institution.

The Register of Copyrights has stated that "the extent to which library photocopying services are large-scale operations with full-time photocopying staff, advertisements soliciting patronage, and consistently substantial output bear directly on the extent to which such services are systematic." 19 This is not to say, however, that libraries that advertise their services and fill large numbers of requests for photocopies of copyrighted materials will be prohibited from justifying their activities under Section 108. An assessment as to whether a highly organized and widely publicized fee-based copying service violates the subsection (g)(2) prohibition against systematic reproduction or distribution requires an analysis of the entire operation. A determination of the extent to which copyright owners have been harmed by the service's activities will also be appropriate.

\section{SECTION 107-FAIR USE}

Section 107 of the act states that the fair use of a copyrighted work is not an infringement of copyright. ${ }^{20}$ The express language of the act ${ }^{21}$ and its legislative history $^{22}$ state that libraries may reproduce and distribute copyrighted works under the fair use exemption. Still, there is disagreement as to the extent to which a library may legally reproduce or distribute copies under Section $107 .^{23}$

In most circumstances a library, acting as the agent for the requester, should be able to do what the requester legally could have done. Indeed, this is the reasoning behind Section 108 , which expressly permits libraries to make copies for users. In addition to the express language of Section 107, guidance may be provided by Section $108(\mathrm{~g})$ as to what copying might be considered fair. ${ }^{24}$

\section{The Purpose of the Use}

The preamble to Section 107 lists certain purposes that are most appropriate for a finding of fair use. Reproduction for the purpose of "scholarship" or "research" is expressly included. However, copying pursuant to one of the enumerated purposes will not always result in a finding of fair use. The section also lists four factors that a court must consider in determining whether a use is fair, although factors other than those enumerated may also be considered. The first factor is "the purpose and character of the use, including whether the use is of a commercial nature or, rather, for nonprofit educational purposes. ${ }^{\prime 25}$ It is therefore appropriate to examine how the reproduced material will be used. 
Outside of requests by educators and students, academic libraries are most frequently requested to reproduce materials for persons who require the materials for their research. ${ }^{26}$ Special libraries commonly receive requests from individuals researching the subject areas that comprise the core of the library's collection. For example, most of the requests received by law libraries from noninstitutional users are from attorneys. The fact that an attorney's research is done with a profit-making motive should not negate a finding of fair use. An attorney's reading of a photocopied article or chapter of a book for background research or for preparation of a client's case should not be deemed a predominant purpose of commercial gain and, therefore, an impermissible use. ${ }^{27}$

Some courts have held that in order to find fair use there must be a productive use of the copied work. ${ }^{28}$ Under the productive use test, the user must add to the work being copied; simply using the work for the purpose for which it was created is not enough. However, the United States Supreme Court recently stated that a nonproductive use may be a fair use. ${ }^{29} \mathrm{Copy}$ ing for the purpose of aiding one's understanding, which is not always a productive use, may be a fair use.

In addition to examining the purpose and character of the requester's use of the material copied, the purpose of the copying service in making and distributing the photocopy also must be considered. That purpose, generally, is to assist in the dissemination of information, and is, at the worst, neutral. The fact that a fee-based copying service charges for the copies should not negate a finding of fair use unless the service receives monies in excess of expenses.

\section{The Nature of the Work Copied}

The second factor to be considered in a fair use analysis is the nature of the copyrighted work. Generally, there is greater latitude to copy factual, educational, scientific, or informational works than there is to copy creative, fictional, or entertainment works. ${ }^{30}$ Certain libraries, such as law libraries, may do a substantial amount of copying from materials that are not protected by copyright at all, including works of the United States government, ${ }^{31}$ court decisions, ${ }^{32}$ statutes, ${ }^{33}$ administrative codes, legislative histories, and records and briefs of cases. Works not protected by copyright may be reproduced without limitation.

\section{The Amount Copied}

The third factor listed in Section 107 is the amount and substantiality of the portion of the work used in relation to the copyrighted work as a whole. Generally, the more that is copied, the less likely it is that there will be a finding of fair use. ${ }^{34}$

\section{Harm to the Copyright Owner}

The final factor, the effect of the use upon the potential market for or value of the copyrighted work, is generally considered the most important of the four factors. ${ }^{35}$ If the market or potential market for a work is harmed by the copying, there is a greater tendency for a court to find that the use was not fair. ${ }^{36}$

Actually, there are two kinds of possible harm to the copyright owner. The first is that rather than relying on the photocopy provided by the library, the user should have purchased a copy of the original work, or at least have paid royalties for the photocopy. The second type of harm requires an analysis of how the original work is used in a succeeding work, or the purpose of the subsequently created work. If the latter work supplants the market of the original, there is a lesser likelihood that there will be a finding of fair use. ${ }^{37}$ As the agent of the ultimate user and as the actual copier, the copying service must consider whether its copying harms the market for or value of the work copied, and whether the ultimate use of the copied work has adversely affected the market for the original.

\section{THE WILLIAMS \& WILKINS CASE}

Only one decision by an American court has examined the limits of fair use for libraries. In Williams \& Wilkins Co. $v$. United States $^{38}$ the United States Court of Claims held that the National Library of Medi- 
cine's copying of entire articles was a fair use because NLM was a nonprofit institution, copying was normally restricted to a single copy of articles less than fifty pages, medical research would be harmed if the copying was disallowed, and the plaintiffpublisher failed to prove that it was harmed by the copying. Affirmed by the United States Supreme Court in a four-tofour decision, Williams $\mathcal{E}$ Wilkins has limited precedent effect.

One may speculate how Williams $\mathcal{E}$ Wilkins would be decided if litigated once again. At the 1975 copyright revision hearings, then Register of Copyrights Barbara Ringer testified that it was unclear whether the National Library of Medicine's activities would be permitted under proposed Section $108 .{ }^{39}$ At that time Section $108(\mathrm{~g})(2)$ did not include the proviso expressly allowing libraries to participate in interlibrary arrangements. The late Professor Alan Latman, however, stated that the proviso is concerned only with arrangements among libraries, and not for situations in which a library reproduces materials directly for its patrons. ${ }^{40}$ In the 1983 Section 108(i) report, the Register of Copyrights commented that in enacting subsection $(g)(2)$ Congress attempted to limit NLM-type operations. ${ }^{41}$ Professor Nimmer, however, while believing the Williams $\mathcal{E}$ Wilkins decision to be erroneous, ${ }^{42}$ also states that "the library reproduction in Williams \& Wilkins was largely within the permissible area of photocopying under Section 108.,"43

\section{LARGE-SCALE COPYING OPERATIONS}

Copyright owners may view libraries as potentially more threatening than commercial photocopy services. While both may have the staff and equipment to engage in large-scale copying, a library also has the documents. Some of these concerns were addressed in Section $108(\mathrm{~g})$, which prohibits a library from engaging in multiple or systematic copying and distribution.

It is possible, of course, that some library fee-based photocopying services may be engaging in activities that cannot be justified under either Section 107 or
108. As discussed earlier, the purpose of Section $108 \mathrm{~g}(\mathrm{~g})(2)$ is to prevent copying that reduces the market for a work. This is essentially identical to the crucial fourth factor that must be considered in a fair-use analysis under Section 107.

A library that advertises its services may have a more difficult time justifying its copying under Section 107. A fair-use analysis would likely consider whether the advertisements were aimed at local patrons only or, instead, to a broader range of patrons who would not normally use the library. The frequency of those advertisements might also be important. The fact that potential users might have paid royalties for the use of an article, purchased a single issue, or subscribed to the journal rather than rely on the photocopy service might convince a court that the library's activities exceeded fair use. ${ }^{44}$

\section{CONCLUSION}

The extent to which a library may reproduce and distribute copies through a feebased photocopy service under either Section 107 or 108 of the Copyright Act requires an examination of the entire operation. What and how much is copied, for whom the copy is made, and how the copy is used must all be considered. So, of course, would the amount charged for the copies and how the revenue is used. The number of clients served by the photocopying service would be considered, as would the extent to which the library solicits patronage through advertisements or other means. Ultimately, the analysis may focus on quantity, as the amount of copying done by the library will likely play a significant role in determining whether copyright owners are actually or potentially being harmed.

The right to reproduce and distribute copyrighted materials under the Copyright Act is not limitless. While the presence of fee-based photocopying services in libraries permits broad dissemination of resources, the continued existence of such services will depend upon compliance with Section 107 and Section 108, judicial interpretation of those sections, and possible legislative changes to the Copyright Act itself. 


\section{REFERENCES AND NOTES}

1. Title 17, U.S. Code, Sections 101-801 (1982)

2. Title 17, U.S. Code, Section 106(1),(3) (1982)

3. H.R. Rep. No. 1476, 94th Cong., 2nd Sess. 75 (1976), reprinted in 1976 U.S. Code Cong. Ad. News 5659 (hereinafter cited as House Report).

4. Ibid., p.74.

5. Ibid.

6. The Interlibrary Loan Study Committee of the Association of Research Libraries initiated a study in 1971 of the interlibrary activities of several academic libraries. The average cost to a lending library providing the original work or a photocopy, per completed request, was $\$ 4.67$. Approximately 43 percent of all materials supplied were photocopies. Vernon Palmour and others, A Study of the Characteristics, Costs, and Magnitude of Interlibrary Loans in Academic Libraries (Westport, Conn.: Greenwood, 1972). A 1977/78 study at the University of Oklahoma Libraries calculated the cost of a completed lending transaction, including both originals and photocopies, to be $\$ 5.45$. Jo Ellen Herstand, "Interlibrary Loan Cost Study and Comparison," RQ 20:249 (Spring 1981).

7. See, e.g., U.S. Copyright Office, Report of the Register of Copyrights: Library Reproduction of Copyrighted Works (17 U.S.C. 108) (Washington, DC: U.S. Copyright Off., Library of Congress, 1983), p.75-86 (hereinafter cited as Register's § 108(i) Report).

8. See generally James Heller and Sarah Wiant, Copyright Handbook (Littleton, Colo.: Rothman [for American Assn. of Law Libraries], 1984), p.16-17; Register's § 108(i) Report, supra note 7, p.68-75.

9. "Notice: Warning Concerning Copyright Restrictions.

"The copyright law of the United States (Title 17, United States Code) governs the making of photocopies or other reproduction of copyrighted material.

"Under certain conditions specified in the law, libraries and archives are authorized to furnish a photocopy or other reproduction. One of these specified conditions is that the photocopy or reproduction is not to be 'used for any purpose other than private study, scholarship, or research.' If a user makes a request for, or later uses, a photocopy of reproduction for purposes in excess of 'fair use,' that user may be liable for copyright infringement.

"This institution reserves the right to refuse to accept a copying order if, in its judgment, fulfillment of the order would involve violation of copyright law." 37 C.F.R. $\$ 201.14$ (1984)

10. Melville Nimmer, a noted expert on copyright law, has difficulty construing this phrase. While Nimmer states that the word private might be contrasted with commercial, he notes that such a construction would effectively exclude copying by libraries in for-profit institutions, which would conflict with Congress' expressed intent not to exclude for-profit libraries from inclusion under $\S$ 108. "Perhaps the only manner in which this apparent conflict between the statutory text and the stated legislative intent could be resolved would be by a somewhat strained construction whereby the word 'private' is held to modify only 'study' and not also 'scholarship,' or 'research.' Otherwise, it would seem that the statutory text might prevail over any contrary expression of legislative intent." Melville Nimmer, Nimmer on Copyright (New York, N.Y.: Matthew Bender, 1984), §8.03 (E)(2)(c) (hereinafter cited as Nimmer).

The Register of Copyrights apparently believes that copying for job-related purposes should not be permitted under $\$ 108$. See Register's $\S 108(i)$ Report, supra note 7, p.225. The Register also warns that a library may not reproduce articles or small excerpts for for-profit information brokers. Id. p.120. Copying for recreational purposes, apparently, cannot be justified under subsection (d)(1).

11. One commentator has written: "The condition that the library have no notice of a user's improper purpose in seeking a copy does not require the library affirmatively to seek any information about his identity, status, or affiliation, or to make any judgments as to a user's intended purpose." James Treece, "Library Photocopying," UCLA Law Review 24:1025,1050 (1977).

The Register states that notice "could be found in a variety of facts and circumstances, meaning that a library, to be safe, should take whatever steps necessary to ensure that it is not performing photocopying services for commercial 'information brokers' unless they have clear permission from the owner of copyright." Register's § 108(i) Report, supra note 7, p.121.

12. The specific reference in $\$ 108(\mathrm{~g})(2)$ to subsection (d) materials means that a library need not postpone copying an article or small excerpt from a work until it has determined that a copy is not available commercially. The subsection (g)(i) prohibition against related or concerted reproduction, however, applies to a broader range of materials, including those specified in subsections (c) and (e) (an entire work or a substantial part of a work). In such cases a library must be satisfied that 
a copy cannot be obtained at a fair price before it can reproduce the material or request that another library provide the copy.

13. $2 \mathrm{M}$. Nimmer, supra note $10, \S 8.03$ (E)(2)(i).

14. H.R. Rep. No. 1733 (Conference), 94th Cong., 2nd Sess. 72-74 (1976), reprinted in 1976 U.S. Code Cong. Ad. News 5810 (hereinafter cited as Conference Report).

15. Guidelines for the Proviso of Subsection 108(g)(2)

1. As used in the proviso of subsection $108(\mathrm{~g})(2)$, the words, ". . . such aggregate quantities as to substitute for a subscription to or purchase of such work" shall mean: "(a) with respect to any given periodical (as opposed to any given issue of a periodical), filled requests of a library or archives (a 'requesting entity') within any calendar year for a total of six or more copies of an article or articles published in such periodical within five years prior to the date of the request. These guidelines specifically shall not apply, directly or indirectly, to any request of a requesting entity for a copy or copies of an article or articles published in any issue of a periodical, the publication date of which is more than five years prior to the date when the request is made. These guidelines do not define the meaning, with respect to such a request, of '. . . such aggregate quantities as to substitute for a subscription to [such periodical].' "'

16. A client of a library copying service may infringe copyright by further reproducing a copy received from the service. The library cannot be responsible for subsequent copying done by its client.

17. Guideline number four states: "The requesting entity shall maintain records of all requests made by it for copies or phonorecords of any materials to which these guidelines apply and shall maintain records of the fulfillment of such requests, which records shall be retained until the end of the third complete calendar year after the end of the calendar year in which the respective request shall have been made."

18. Guideline number three states: "No request for a copy or phonorecord of any material to which these guidelines apply may be filled by the supplying entity unless such request it accompanied by a representation by the requesting entity that the request was made in conformity with these guidelines."

19. Register's § 108(i) Report, supra note 7, p.140. The Register also stated "it is arguable that the permanent assignment of staff members to make photocopies for patrons makes the photocopying done by those employees look rather systematic." Id. p.190. Discussing document delivery by means of telefacsimile transmission, the Register wrote: "In copyright terms the use of telefacsimile can be analyzed to the mailing of photocopies. However, because of the high cost of telefacsimile a significant number of copies must be transmitted in order for the technology to be cost effective. Transmission of copies on such a large scale would increase the likelihood that the copying would be found to be 'systematic' under $\$ 108(\mathrm{~g})(2)$. " Ibid., p. 262.

20. Section 107 states: "Notwithstanding the provisions of section 106, the fair use of a copyrighted work, including such use by reproduction in copies or phonorecords or by any other means specified by that section, for purposes such as criticism, comment, news reporting, teaching (including multiple copies for classroom use), scholarship, or research, is not an infringement of copyright. In determining whether the use made of a work in any particular case is a fair use the factors to be considered shall include-

(1) the purpose and character of the use, including whether such use is of a commercial nature or is for nonprofit educational purposes;

(2) the nature of the copyrighted work;

(3) the amount and substantiality of the portion used in relation to the copyrighted work as a whole; and

(4) the effect of the use upon the potential market for or value of the copyrighted work."

21. Section 108(f)(4) states: "Nothing is this section . . . in any way affects the right of fair use as provided by section 107 "

22. House report, supra note 3 , p.78-79.

23. The Register of Copyrights has stated that "fair use privileges are not available on a broad and recurring basis once the copying permitted by $\$ 108$ has occurred." Register's $\S 108(i)$ Report, supra note 7, p.96. He also commented that "just as commercial copiers may not avail themselves of their library customers' copying privileges, it may be that libraries cannot avail themselves of their patrons' copying privileges." Id. p.101. The Register discusses the relationship between $\S 107$ and $\S 108$ in depth at pages $95-104$ of the Report.

The Authors League of America and the Association of American Publishers believe that libraries may reproduce copyrighted works only under $\S 108$. Association of American Publishers and the Authors League of America, Photocopying by Academic, Public, and Nonprofit Research Libraries (1978), p.4,16. Professor James Treece, however, maintains that: "What a user may do for himself, he may have another do for him. Thus 'copyshops,' 'other' libraries and subsection (a) 
libraries may, in a particular transaction, reproduce single or multiple copies or phonorecords of a copyrighted work, not as a library or archive exercising a privilege under $\S 108$, but as the agent of a user possessing a fair use privilege." James Treece, "Library Photocopying," UCLA Law Review 24:1025, 1039 (1977).

24. The Register of Copyrights, discussing the relationship of $\S 107$ and $\S 108$, wrote: "In the $108(\mathrm{i})$ review process, so much emphasis was placed by the participants on ILL transactions, which are governed by $(g)(2)$, that there is little comment on the record about what subsection $(\mathrm{g})(1)$ is perceived to mean or how it is applied in practice. Many librarians do state, however, that there should be no library liability if a patron has fair use privileges (footnote omitted).

The Copyright Office does not agree and, as explained above, believes that related and concerted copying of which the library is aware or has substantial reason to believe it is doing is prohibited, without regard to whether the user could successfully invoke a fair use defense to an action for copyright infringement." Register's § 108(i) Report, supra note 7, p.128-129.

25. However, copying for a nonprofit educational purpose is not always fair. See, e.g., Marcus v. Rowley, 695 F.2d 1171 (9th Cir. 1983) (substantial copying by a public school teacher was held not to be a fair use, notwithstanding the nonprofit educational nature of the use, because the copy was used for the same intrinsic purpose for which the copyright owner intended it to be used); Encyclopaedia Brittanica Educational Corp. v. Crooks, 542 F.Supp. 1156 (W.D.N.Y. 1982) (extensive and systematic copying by a nonprofit educational organization was held not to be a fair use).

26. The 1982 King Research report included data on library staff photocopying of library materials. Academic libraries reported that 22.1 percent of the photocopies provided by library staff were made for students, 32.6 percent were for teachers, 17.2 percent were for employees of the institution other than teachers (these copies possibly could have been made by library staff for other users), and 28 percent were for requesters whose status was unknown or who did not fall into the student, teacher, or employee category. In public libraries, 10.2 percent of the photocopies made by library staff were for students, 1 percent were for teachers, 57.1 percent were for library employees, and 31.7 percent were "other" or "'unknown." King Research, Inc., Libraries, Publishers, and Photocopying: Final Report of Surveys Conducted for the United States Copyright Office (Rockville, MD: King Research, 1982), table 3.9.

27. The fact that the user seeks to profit financially will not necessarily preclude a finding of fair use. See e.g., Triangle Publications Inc. v. Knight-Ridder Newspapers, Inc., 626 F.2d 1171, 1175-76 (5th Cir. 1980); Rosemont Enterprises v. Random House, Inc., 366 F.2d. 303,307-08 (2nd Cir. 1966), cert. denied, 385 U.S. 1009 (1967); N.Y. Times v. Roxbury Data Interface, Inc., 434 F.Supp 217,221 (D.N.J. 1977).

The Register of Copyright's apparent belief that copying for job-related purposes is impermissible under $\S 108$ would likely be no different under a fair use analysis. He stated: "Congress may need to consider the extent to which copyright owners should be obliged to contribute, without compensation, to the money-making activities of those library patrons whose photocopying is job related." Register's § 108(i) Report, supra note 7, p. 225.

28. The United States Court of Appeals for the Ninth Circuit used this rationale in finding that home copying of television programs for personal use was not fair use. In the Betamax case the court wrote: "[F]air use ... has always had to do with the use by a second author of a first author's work. Fair use has not heretofore had to do with the mere reproduction of a work in order to use it for its intrinsic purpose-to make what might be called 'ordinary' use of it." Universal City Studios v. Sony Corp. of America, 659 F.2d 963, 970 (9th Cir. 1981), citing, with approval Leon Seltzer, Exemptions and Fair Use in Copyright, (Cambridge, Mass.: Harvard Univ. Press, 1978), p.24.

29. 'The distinction between 'productive' and 'unproductive' uses may be helpful in calibrating the balance, but it cannot be wholly determinative. . . . Copying for commercial gain has a much weaker claim to fair use than copying for personal enrichment. But the notion of social 'productivity' cannot be a complete answer to this analysis. A teacher who copies to prepare lecture notes is clearly productive. But so is the teacher who copies for the sake of broadening his personal understanding of his specialty, or a legislator who copies for the sake of broadening her understanding of what her constituents are watching; or a constituent who copies a news program to help make a decision on how to vote." Sony Corp. of America v. Universal City Studios, 464 U.S. 417, 455 n.40 (1984).

30. See e.g., N.Y. Times v. Roxbury Data Interface, Inc. 434 F.Supp 217,221 (D.N.J. 1977). But cf. Harper \& Row, Publishers, Inc. v. Nation Enterprises, 105 S.Ct. 2218 (1985); Sony Corp. of America v. Universal City Studios, 464 U.S. 417 (1984), reh'g. denied, 104 S.Ct. 1619 (1984).

31. 17 U.S.C. $\S 105$ (1982). 
32. Wheaton v. Peters, 33 U.S. (8 Peters) 334 (1834).

33. See Bldg. Officials and Code Adm'rs., Inc. v. Code Technology, Inc. 628 F.2d 730 (1st Cir. 1980); Ga. v. Harrison Co., 548 F.Supp 110 (N.D. Ga. 1982), order vacated, 559 F.Supp. 37 (N.D. Ga. 1983).

34. See, e.g., Walt Disney Productions v. Air Pirates, 581 F.2d 751,757-58 (9th Cir. 1978) cert. denied 439 U.S. 1132 (1979); Quinto v. Legal Times of Washington, Inc., 506 F.Supp. 554,560 (D.D.C. 1981). But cf. Sony Corp. of America v. Universal City Studios, 464 U.S. 417 (1984), reh'g. denied, 104 S.Ct. 1619 (1984); Williams \& Wilkins Co. v. United States 487 F.2d 1345 (Ct.Cl. 1973), aff'd by an equally divided court, 420 U.S. 376 (1975).

35. Both the majority and dissenting opinions in The Nation decision focus on harm to the copyright owner as the most crucial of the four factors. Justice O'Connor, writing for the majority, stated: "This last factor is undoubtedly the single most important element of fair use." 105 S.Ct. at 2234.

In his dissent, Justice Brennan wrote: "The Court correctly notes that the effect on the market 'is undoubtedly the single most important element of fair use.' " 105 S.Ct. at 2252 (Brennan, J., dissenting).

See also Alan Latman, The Copyright Law: Howell's Copyright Law Revisited and the 1976 Act (Washington, DC: Bureau of National Affairs, 5th ed. 1979), p.214; 2 M. Nimmer, supra note 10, $\$ 13.05$ (A)(4).

36. The House Committee on the Judiciary warned that the scope of the fair use doctrine should be very narrow in the case of profit-making users of newsletters, which are generally of modest length and have limited circulation. House Report, supra note 3, p.73-74.

37. See, e.g., Quinto v. Legal Times of Washington, Inc., 506 F.Supp. 554,560 (D.D.C. 1981).

38. 487 F.2d 1345 (Ct. Cl. 1973), aff'd by an equally divided court, 420 U.S. 376 (1975).

39. "Suppose, for example, that the bill were enacted in its present form and Williams $\mathcal{E}$ Wilkins reinstituted suit under the new law. The Court of Claims has held that what the National Library of Medicine was doing constituted fair use under the 1909 law. Would section 108 change that result? And the Senate report, the 1974 Senate report, doesn't give you a clue as to the answer." Copyright Law Revision: Hearings on H.R. 2223 Before the Subcommittee on Courts, Civil Liberties, and the Administration of Justice of the House Committee on the Judiciary, 94th Cong., 1st Sess. 1799 (1975) (hereinafter cited as Hearings).

40. "This proviso, which addresses itself only to the interlibrary situation and not reproduction by a library directly for its patrons, was accepted in the House-passed version of S.22." Alan Latman, The Copyright Law: Howell's Copyright Law Revisited and the 1976 Act (Washington, DC: Bureau of National Affairs, 5th ed. 1979), p.219.

41. "Its [subsection (g)(2)'s] first appearance in the revision process was apparently in response to the Court of Claims' holding that the large-scale, routine photocopying done by NIH/NLM did not infringe William \& Wilkins' copyrights. Looking at the language in the Commissioner's and Court's opinions, it is reasonable to infer that Congress' action in introducing g) (2) [sic] ihe [sic] legislation, coming on the heels of that decision, reflected a judgment that the copying there was 'systematic' and that thus Congress was attempting to render it infringing. " Register's $\$ 108(i)$ Report, supra note 7, p. 130 .

42. $3 \mathrm{M}$. Nimmer, supra note $10, \S 13.05[\mathrm{E}][4][\mathrm{c}]$.

43. Ibid., $\S 13.05[\mathrm{E}][4][\mathrm{d}]$.

The CONTU Commission warned that operations established for the exclusive purpose of providing photocopies would not be protected by $\S 108$. "[T]he Commission believes that non-profit centers established for the specific purpose of providing copies would be required to secure authorization from copyright owners to make and distribute full scale copies of periodical articles from the original issues as well as to make microforms." National Commission on New Technological Uses of Copyrighted Material, Final Report (Washington, DC, 1978), p.163.

At the 1975 Copyright revision hearings, Register Ringer stated: "A line must be drawn between legitimate interlibrary loans using photocopies instead of bound books, and prearranged understandings that result in a particular library agreeing to become the source of an indeterminate number of photocopies." Hearings, supra note 39, p.1,801.

One other commentator has stated that in enacting $\$ 108$ Congress "indicated its disapproval of the Court of Claims' fair use holding. " William Patry, The Fair Use Privilege in Copyright Law (Washington, DC: Bureau of National Affairs, 1985), p.184.

See also, Conference Report, supra note 14, p.72.

44. The Register's $\S 108$ (i) Report suggested that a highly organized large-scale operation might be considered systematic, and thus prohibited under $\S 108(\mathrm{~g})(2)$. See text, p.14-15, supra. 